Young organic matter as a source of carbon dioxide outgassing from Amazonian rivers

E. Mayorga, A. K. Aufdenkampe, C. A. Masiello, A. V. Krusche, J. I. Hedges, P. D. Quay, J. E. Richey, T. A. Brown

July 20, 2005

Nature 
This document was prepared as an account of work sponsored by an agency of the United States Government. Neither the United States Government nor the University of California nor any of their employees, makes any warranty, express or implied, or assumes any legal liability or responsibility for the accuracy, completeness, or usefulness of any information, apparatus, product, or process disclosed, or represents that its use would not infringe privately owned rights. Reference herein to any specific commercial product, process, or service by trade name, trademark, manufacturer, or otherwise, does not necessarily constitute or imply its endorsement, recommendation, or favoring by the United States Government or the University of California. The views and opinions of authors expressed herein do not necessarily state or reflect those of the United States Government or the University of California, and shall not be used for advertising or product endorsement purposes. 


\section{Young organic matter as a source of carbon dioxide outgassing from Amazonian rivers}

Emilio Mayorga ${ }^{1}$, Anthony K. Aufdenkampe ${ }^{2}$, Caroline A. Masiello ${ }^{3}$, Alex V.

Krusche $^{4}$, John I. Hedges ${ }^{1, \dagger}$, Paul D. Quay ${ }^{1}$, Jeffrey E. Richey ${ }^{1} \&$ Thomas A. Brown ${ }^{5}$

${ }^{1}$ School of Oceanography, University of Washington, Seattle, WA 98195, USA

${ }^{2}$ Stroud Water Research Center, Avondale, PA 19311, USA

${ }^{3}$ Department of Earth Science, Rice University, Houston, TX 77005, USA

${ }^{4}$ Laboratório de Ecologia Isotópica, CENA-USP, 13400-970 Piracicaba SP, Brazil

${ }^{5}$ Center for Accelerator Mass Spectrometry, Lawrence Livermore National Laboratory, Livermore, CA 94551, USA

E.M. and A.K.A. contributed equally to this work.

Correspondence and request for materials should be addressed to E.M. (emiliomayorga@alum.mit.edu).

${ }^{\dagger}$ Deceased.

Rivers are generally supersaturated with respect to carbon dioxide, resulting in large gas evasion fluxes that can be a significant component of regional net carbon budgets $^{1,2}$. Amazonian rivers were recently shown to outgas more than ten times the amount of carbon exported to the ocean in the form of total organic carbon or dissolved inorganic carbon ${ }^{1}$. High carbon dioxide concentrations in rivers originate largely from in situ respiration of organic carbon ${ }^{1-3}$, but little agreement exists about the sources or turnover times of this carbon ${ }^{2,4,5}$. Here we present results of an extensive survey of the carbon isotope composition $\left({ }^{13} \mathrm{C}\right.$ and $\left.{ }^{14} \mathrm{C}\right)$ of dissolved inorganic carbon and three size-fractions of organic carbon across the Amazonian river system. We find that respiration of contemporary organic 
matter (less than 5 years old) originating on land and near rivers is the dominant source of excess carbon dioxide that drives outgassing in mid-size to large rivers, although we find that bulk organic carbon fractions transported by these rivers range from tens to thousands of years in age. We therefore suggest that a small, rapidly cycling pool of organic carbon is responsible for the large carbon fluxes from land to water to atmosphere in the humid tropics.

Riverine $\mathrm{CO}_{2}$ concentrations in Amazonian lowlands are 5-30 times supersaturated with respect to atmospheric equilibrium ${ }^{1}$; such conditions may be prevalent throughout the humid tropics. In situ respiration is the primary source of $\mathrm{CO}_{2}$ sustaining supersaturation in rivers, although inputs from groundwater supersaturated by soil respiration can be important in small systems and from submerged riparian root respiration in floodplain influenced systems ${ }^{1-3,6-8}$. While air-water gas exchange is a bidirectional process, atmospheric $\mathrm{CO}_{2}$ invasion has a negligible role compared to the large $\mathrm{CO}_{2}$ evasion fluxes, except at low supersaturation ${ }^{2,3,6,7} \cdot{ }^{13} \mathrm{C}$ and ${ }^{14} \mathrm{C}$ isotopes can provide constraints on sources and turnover times of organic carbon (OC) fuelling river respiration, yet no previous tropical study has used a dual-isotope approach to address these questions. Studies in temperate eastern USA provide contrasting findings. In the Hudson River, up to $70 \%$ of the centuries-old terrestrial OC entering the river is respired in transit, and the average age of riverine OC decreases downstream ${ }^{2}$. However, the youngest components of dissolved OC (DOC) are preferentially respired in the York River ${ }^{5}$, and modern dissolved inorganic carbon (DIC) in the Parker River may be explained by respiration of young DOC produced within the estuary ${ }^{4}$. Documenting key patterns and controls on $\mathrm{CO}_{2}$ sources in diverse ecosystems is critical to advance our understanding of $\mathrm{CO}_{2}$ outgassing from rivers and its contribution to regional net carbon budgets. 
To identify dominant sources and turnover times of riverine carbon throughout the Amazon basin, we analysed ${ }^{14} \mathrm{C}$ and ${ }^{13} \mathrm{C}$ of DIC, DOC, and suspended fine and coarse particulate OC fractions (FPOC and CPOC), grouping sites topographically (Fig. 1). This survey represents the most extensive dual carbon isotope inventory to date in a large, diverse basin, and the first ${ }^{14} \mathrm{C}$ analysis of DIC in Amazonian rivers. It complements but greatly exceeds previous carbon isotope surveys ${ }^{5,7,9}$, enabling an integrated assessment of carbon cycling.

DIC is composed of dissolved $\mathrm{CO}_{2}$ and bicarbonate and carbonate ions in $\mathrm{pH}-$ dependent chemical and isotopic equilibrium ${ }^{10}$. In studies of marine and homogeneous river systems, where $\mathrm{pH}$ is nearly uniform, it has been the convention to report the isotopic composition of total DIC, which is directly measured. However, when the turnover of DIC by $\mathrm{CO}_{2}$ fluxes is as rapid as in many of these tropical rivers, a quasisteady-state condition constrains the isotopic composition of outputs by $\mathrm{CO}_{2}$ outgassing to equal that of inputs by $\mathrm{CO}_{2}$ production from respiration ${ }^{7,8}$. In response to this preeminence of $\mathrm{CO}_{2}$ sources and the large range of observed $\mathrm{pH}$ (3.8 to 8.7), we base our analysis on the calculated isotopic values of $\mathrm{CO}_{2}$ gas in equilibrium with DIC, avoiding the need to discuss the isotopic variation in ${ }^{13} \mathrm{C}$ of DIC caused by changes in $\mathrm{pH}$ alone (see Methods and Supplementary Discussion). We report measured $\delta^{13} \mathrm{C}$-DIC in Table S3. For ${ }^{14} \mathrm{C}$ we use $\Delta^{14} \mathrm{C}$ notation, which includes a correction for ${ }^{13} \mathrm{C}$ such that $\Delta{ }^{14} \mathrm{C}$ of $\mathrm{CO}_{2}$ and DIC are equal at any $\mathrm{pH}$ (ref. 11).

$\mathrm{CO}_{2}$ in nearly all lowland rivers had a $\Delta^{14} \mathrm{C}$ signature bound within the range of local atmospheric $\Delta^{14} \mathrm{C}-\mathrm{CO}_{2}$ estimated for the lowland DIC sampling period (19962003, Fig. 2; Methods). Testing of thermonuclear bombs resulted in a large increase in atmospheric ${ }^{14} \mathrm{CO}_{2}$, reaching a peak in the late 1960 s and steadily decreasing afterwards $^{12,13}$. Continual change in atmospheric radiocarbon content necessitates that we assess the mean age for modern carbon samples by the offset between riverine $\Delta^{14} \mathrm{C}$ 
and the sampling year's annual mean atmospheric $\Delta^{14} \mathrm{C}-\mathrm{CO}_{2}$ (ref. 14). From 1996 to 2003, $\Delta^{14} \mathrm{C}-\mathrm{CO}_{2}$ at four supersaturated sites in mid to large lowland rivers decreased by $32-42 \%$, equivalent to the annually averaged atmospheric $\Delta^{14} \mathrm{C}-\mathrm{CO}_{2}$ decrease of $36 \%$ ($5.6 \pm 2.3 \% \mathrm{yr}^{-1}$ ) (Fig. 3). Thus, atmospheric offsets remained roughly constant, suggesting constant respiratory OC turnover times for each basin. The range of these offsets suggests rapid turnover of photosynthetically sequestered atmospheric $\mathrm{CO}_{2}$; outgassed $\mathrm{CO}_{2}$ is derived from atmospheric $\mathrm{CO}_{2}$ sequestered within $<4$ years in the midsized Ji-Parana basin ( $\Delta^{14} \mathrm{C}$ offsets: $\left.14 \pm 6 \%, \mathrm{n}=8\right)$ and 4-7 years previously at the Rio Negro mouth ( $\left(\Delta^{14} \mathrm{C}\right.$ offsets: $29 \pm 9 \%, \mathrm{n}=3$ ).

Rapid carbon turnover is likely widespread across Amazonian rivers. However, DIC from carbonate mineral weathering, with its typically enriched $\delta^{13} \mathrm{C}$ and highly depleted $\Delta^{14} \mathrm{C}$ (Fig. 2), commonly obscures the influence of respiration. To focus on sites where DIC originates largely as respired $\mathrm{CO}_{2}$, we identified sites draining substantial carbonate lithologies through their inorganic solute composition ${ }^{15}$ (Methods and Supplementary Discussion). Only lowland sites had little potential for direct, substantial carbonate contributions to DIC (38 samples in 25 lowland sites, Fig. S1). Observations in carbonate-free lowlands contained supersaturated, predominantly contemporary $\mathrm{CO}_{2}$ (Table 1, Fig. 2) and could be divided into two groups based on atmospheric $\Delta^{14} \mathrm{C}-\mathrm{CO}_{2}$ offsets. The largest group (32 samples from 21 sites) encompassed first-order streams and large rivers carrying contemporary $\mathrm{CO}_{2}$ with atmospheric $\Delta^{14} \mathrm{C}-\mathrm{CO}_{2}$ offsets ranging from -3 to $38 \%$ o $(14 \pm 11 \%$ ), indicating a mean $\mathrm{CO}_{2}$ age of approximately 2 years, and $<5$ years in $87 \%$ of the observations; enriched $\delta^{13} \mathrm{C}^{-} \mathrm{CO}_{2}$ in the Ji-Parana region $(-17.5 \pm 2.2 \%$, $\mathrm{n}=21)$ suggest a $\mathrm{C}_{4}$ plant influence. The second group of carbonate-free observations consisted of 6 samples in 3 small and 2 mid-sized rivers in the Ji-Parana region having considerable negative $\Delta^{14} \mathrm{C}$ offsets ($32 \pm 21 \%$ ), indicating a mean source age of several decades. Relatively depleted $\delta^{13} \mathrm{C}$ $\mathrm{CO}_{2}$ values (-20.0土1.7\%o) compared to Ji-Parana rivers from the first group suggest an 
influence from groundwater influx of aged soil $\mathrm{CO}_{2}$ with a significant terrestrial $\mathrm{C}_{3}$ plant source relative to other rivers in that highly deforested region. In both groups, respiration of submerged tree and grass roots can be excluded as important $\mathrm{CO}_{2}$ sources because our dataset was predominantly collected during low water.

Isotopic signatures in carbonate-free lowland rivers demonstrate that $\mathrm{CO}_{2}$ originated from heterotrophic respiration of contemporary $\mathrm{C}_{3}$ and $\mathrm{C}_{4}$ organic carbon (Fig. 2), yet $\mathrm{CO}_{2}$ appears isotopically distinct from the associated bulk OC load. All OC fractions were considerably depleted in ${ }^{13} \mathrm{C}$ relative to $\mathrm{CO}_{2}$ (Table 1, Fig. 2, and Supplementary Discussion). Furthermore, DOC was generally older than $\mathrm{CO}_{2}$, FPOC showed a bimodal distribution with ages similar to $\mathrm{CO}_{2}$ in non-turbid rivers and older carbon in high-sediment rivers, and CPOC exhibited a wide range of ages. We conclude that in situ respiration is fuelled largely by an unmeasured organic subfraction that cycles on the order of $<5$ years and typically makes up a small component of the riverine $\mathrm{OC}$ load. ${ }^{13} \mathrm{C}$ enrichment of $\mathrm{CO}_{2}$ relative to $\mathrm{OC}$ indicates that this missing OC source fuelling river respiration is disproportionately composed of riparian and floodplain $\mathrm{C}_{4}$ grasses, which may be intrinsically more biodegradable ${ }^{7,16}$.

Mountain and mixed rivers contain older dissolved $\mathrm{CO}_{2}\left(\Delta^{14} \mathrm{C}=-749\right.$ to $96 \%$ o $)$ with clear carbonate mineral dissolution signatures. However, observed $\mathrm{CO}_{2}$ supersaturation in these rivers must be generated by $\mathrm{CO}_{2}$ sources other than carbonates (Supplementary Discussion). These $\mathrm{CO}_{2}$ fluxes gradually flush out geologically derived $\mathrm{DIC}$, replacing its isotopic signature. Indeed, a $\mathrm{CO}_{2}$ trend of increasing $\Delta^{14} \mathrm{C}$ and decreasing $\delta^{13} \mathrm{C}$ is observed from the Peruvian Andes to the Amazon mainstem, with $\Delta{ }^{14} \mathrm{C}-\mathrm{CO}_{2}$ reaching $30-76 \%$ in the central mainstem, still below atmospheric levels (Fig. 2). Along the Ucayali and western-central mainstem, inputs of likely young $\mathrm{CO}_{2}$ from in situ respiration and lowland tributaries drive large evasion fluxes of ${ }^{14} \mathrm{C}$ depleted $\mathrm{CO}_{2}$ derived from carbonate dissolution. In the more arid Ucayali mountain 
headwaters, highly depleted $\Delta^{14} \mathrm{C}-\mathrm{CO}_{2}(<-500 \%)$, enriched $\delta^{13} \mathrm{C}-\mathrm{CO}_{2}(\sim-11 \%)$, and considerable $\mathrm{CO}_{2}$ supersaturation point to solid-earth degassing as a large dry-season $\mathrm{CO}_{2}$ source, as documented in other tectonically active mountain ranges ${ }^{17}$.

Control of respiration by a small fraction of OC does not imply that bulk OC is unreactive. On the contrary, measured OC fractions appear to be mineralised throughout the river system. The strongest evidence is that FPOC generally becomes younger and more depleted in ${ }^{13} \mathrm{C}$ downstream from mountain sites (Fig. 2, Table 1), where all OC fractions mirror the high-altitude ${ }^{13} \mathrm{C}$ enrichment in plants of $\sim 1 \%$ per $1000 \mathrm{~m}^{\text {elevation }}{ }^{18,19}$. Within $1000 \mathrm{~km}$ from mountain headwaters, $\delta^{13} \mathrm{C}$-FPOC becomes nearly undistinguishable from lowland carbon. With FPOC tightly associated with mineral surfaces ${ }^{19,20}$, no downstream changes in the ratio of FPOC to fine suspended sediment concentration ( $0.8-1.5 \%$, Table S2), and $>85 \%$ of the Amazon mainstem mineral load ultimately originating in the Andes ${ }^{21}$, this observation implies nearly complete mineralization of old Andean FPOC and replacement with new lowland OC during transit within the river or during long-term flooplain storage ${ }^{7}$. Even if all FPOC leaving the Andes were mineralised within the river channel, the resulting $\mathrm{CO}_{2}$ flux would be $1 / 40$ of total $\mathrm{CO}_{2}$ evasion fluxes ${ }^{1}$, hardly impacting the isotopic signature of $\mathrm{CO}_{2}$. CPOC and DOC descending from the Andes follow identical trends of gradual ${ }^{13} \mathrm{C}$ depletion to lowland values (Fig. 2), although without a conservative mineral carrier as for FPOC, simple dilution by lowland OC can not be ruled out. DOC is generally modern $(<50$ years old) everywhere, demonstrating that old DOC does not escape from the basin.

Isotopic evidence for dominance of respiration fluxes by a rapidly cycling, typically small fraction of total OC confirms the hypothesis previously posited for the Amazon mainstem from respiration ${ }^{8,16},{ }^{13} \mathrm{C}$ (ref. 7), and mass balance studies ${ }^{1,7}$. It implies that gradual consumption or replacement of old fractions in bulk OC can occur in parallel 
with high rates of respiration of a highly labile OC subfraction. This paradigm has been advanced for tropical and temperate soils ${ }^{22}$, providing strong conceptual linkage between aquatic and terrestrial carbon dynamics ${ }^{23}$. It suggests that deforestation in Amazonia leads to immediate changes to the organic sources of riverine heterotrophic energy and argues that such impact is not inconsistent with apparent lag times observed in bulk OC composition ${ }^{24}$. While the mechanism proposed here may be widespread across the humid tropics ${ }^{1}$ and appears consistent with radiocarbon observations from temperate rivers ${ }^{2,4,5}$, it is probable that certain river systems, such as those draining eroding peats, are fuelled by old organic carbon. Explicit accounting of isotopic signatures of $\mathrm{CO}_{2}$ outgassing from different river types may be required to accurately interpret isotope-based regional tropospheric $\mathrm{CO}_{2}$ inversions.

\section{Methods}

Sample collection and analysis. Samples analysed for ${ }^{14} \mathrm{C}$-DIC were collected between 1991 and 2003, whereas ${ }^{14} \mathrm{C}-\mathrm{OC}$ samples are from 1995-1996. All samples were preserved with mercuric chloride immediately after collection at mid-depth from the deepest section of the channel. DIC samples were prepared as described in Quay et $a l{ }^{7}$ and stored in tightly capped glass bottles for up to 24 months; in the lab, the top half of the bottle was drawn into a vacuum line (eliminating particles) and stripped of $\mathrm{CO}_{2}$ after acidification ${ }^{7}$. CPOC $(63-2000 \mu \mathrm{m})$ was isolated either by sieving or with a plankton net, FPOC (0.1-63 $\mu \mathrm{m})$ by tangential flow microfiltration, and DOC (1000 atomic mass units to $0.1 \mu \mathrm{m}$ ) by tangential flow ultrafiltration ${ }^{19}$; final concentration and drying was achieved by centrifugal evaporation or freeze drying ${ }^{19}$, and the dried powder stored in the dark at ambient temperature for up to 6 years. Ultrafiltration yields ranged from $40 \%$ in the Andes to $80 \%$ in the lowlands ${ }^{19,25}$. Organic samples were combusted as in Quay et $a l^{7}$. Cryogenically purified $\mathrm{CO}_{2}$ from OC and DIC was analysed for stable isotope and radiocarbon by dual-inlet Isotope Ratio Mass Spectrometry and 
Accelerator Mass Spectrometry (AMS $)^{26}$, respectively; $>90 \%$ of ${ }^{14} \mathrm{C}$ analyses were carried out at the Lawrence Livermore National Laboratory's Center for Accelerator Mass Spectrometry, and the rest at the University of Arizona AMS Laboratory. $\mathrm{CO}_{2}$ extracted from DIC was stored in sealed glass ampules for up to 8 years. ${ }^{13} \mathrm{C}$ is reported in $\delta^{13} \mathrm{C}$ notation vs. the PDB standard ${ }^{10}$. Radiocarbon values are reported as agecorrected $\Delta^{14} \mathrm{C}$ adjusted for sample $\delta^{13} \mathrm{C}$ (ref. 11); carbon is defined as modern when it originates after 1890 (ref. 11). Absolute $\Delta^{14} \mathrm{C}$ and $\delta^{13} \mathrm{C}$ analysis errors $(1 \sigma)$ are typically $<6 \%$ and $<0.2 \%$, respectively. Isotopes for all carbon fractions were not always analysed at each site. Additional analyses include $\mathrm{pH}$, major ions, alkalinity, and total carbon fraction concentrations (Table S2). Major ions were quantified by ion chromatography. Alkalinity was measured by Gran titration, or estimated from temperature, $\mathrm{pH}$, and DIC when not measured. $\mathrm{CO}_{2}$ concentrations were either measured directly by headspace equilibration (Aufdenkampe, manuscript in preparation) or estimated from temperature, pressure, $\mathrm{pH}, \mathrm{DIC}$, and alkalinity. Sampling sites are grouped by topographic characteristics (Fig. 1). In the discussion, grouped observations are reported as mean \pm standard deviation (number of samples) and compared only qualitatively due to low number of samples per group.

Isotopic calculation of $\mathrm{CO}_{2}$ gas in equilibrium with DIC. DIC is composed of dissolved carbonate species $\left(\mathrm{H}_{2} \mathrm{CO}_{3}(\mathrm{aq}), \mathrm{HCO}_{3}{ }^{-}(\mathrm{aq})\right.$, and $\left.\mathrm{CO}_{3}{ }^{2-}(\mathrm{aq})\right)$ in $\mathrm{pH}$ - and temperature-dependent equilibrium with one another. Isotopic fractionation occurs during conversion from one species to another and dissolution of $\mathrm{CO}_{2}$ gas $^{10} ; \mathrm{CO}_{2}$ gas is hereafter referred to as simply $\mathrm{CO}_{2} . \delta^{13} \mathrm{C}$ of $\mathrm{CO}_{2}$ gas in equilibrium with DIC is calculated from measured $\delta^{13} \mathrm{C}$-DIC and $\mathrm{pH}$, and from temperature-dependent isotopic equilibrium fractionations between $\mathrm{CO}_{2}$ and DIC species ${ }^{10,27} \cdot \mathrm{pH}$ can vary dramatically in a large basin and is largely a function of weathering lithologies (Table S2). $\Delta^{14} \mathrm{C}$ is defined to be insensitive to mass-dependent fractionation ${ }^{11}$; as a result $\Delta^{14} \mathrm{C}-\mathrm{CO}_{2}=$ $\Delta^{14} \mathrm{C}$-DIC. While a focus on isotopes of $\mathrm{CO}_{2}$ instead of DIC is unconventional, it yields 
more straightforward assessments of the impact of respiration and air-water gas exchange on DIC across geochemically diverse rivers.

Radiocarbon trends in atmospheric $\mathbf{C O}_{2}$. Measurements from Schauinsland Station, Germany, were used to characterise atmospheric $\Delta^{14} \mathrm{C}-\mathrm{CO}_{2}$ from 1991 to 2003 (refs. 12,14). The uncharacterised effect of seasonal and short-term atmospheric variability is minimized by comparing river ${ }^{14} \mathrm{C}$ only against time-weighted annual means ${ }^{14}$. A constant $+8 \%$ offset was added to Schauinsland annual means to account for a $5 \%$ depletion from regional fossil-fuel emissions at Schauinsland relative to the well-mixed, mid-latitude European troposphere (Jungfraujoch $\operatorname{site}^{14}$ ), and approximately 3\%o further depletion at the mid-latitude troposphere relative to tropical South America ${ }^{12,13}$. Atmospheric $\Delta^{14} \mathrm{C}-\mathrm{CO}_{2}$ composition within the Amazon basin is unknown, but seasonal and regional variability may be as large as $10 \%$ (ref. 13). Riverine $\Delta^{14} \mathrm{C}$ values within $5 \%$ of our estimated atmospheric annual average for the sampling year likely represent carbon turnover times of one year or less. Mid-1990s tropospheric $\mathrm{CO}_{2}$ can be characterized by a partial pressure $\left(\mathrm{pCO}_{2}\right)$ of $370 \mathrm{ppm}$ and $\delta^{13} \mathrm{C}$ composition of $-8 \%$ (refs. 10,12,13).

Carbonate mineral dissolution and DIC. Carbonate weathering is a source of high DIC concentrations enriched in $\delta^{13} \mathrm{C}$ and highly depleted in $\Delta^{14} \mathrm{C}$ when, as is most common, it involves the dissolution of ${ }^{14} \mathrm{C}$-dead carbonate minerals $\left(\mathrm{CaCO}_{3}(\mathrm{~s})\right)$ by carbonic acid $\left(\mathrm{H}_{2} \mathrm{CO}_{3}(\mathrm{aq})\right)$ from respired modern plant matter in soils (Fig. 2 and Supplementary Discussion). We used alkalinity and dissolved inorganic cation composition to identify sites draining substantial carbonate lithologies ${ }^{15}$ (Fig. S1). While exchange with the atmosphere or input of respired $\mathrm{CO}_{2}$ may erase the isotopic signature of carbonate dissolution, we identified and excluded carbonate-influenced sites in order to unambiguously focus on the isotopic relationship between organic carbon and DIC. 
1. Richey, J. E., Melack, J. M., Aufdenkampe, A. K., Ballester, M. V. \& Hess, L. L. Outgassing from Amazonian rivers and wetlands as a large tropical source of atmospheric $\mathrm{CO}_{2}$. Nature 416, 617-620 (2002).

2. Cole, J. J. \& Caraco, N. F. Carbon in catchments: Connecting terrestrial carbon losses with aquatic metabolism. Marine and Freshwater Research 52, 101-110 (2001).

3. Mulholland, P. J. et al. Inter-biome comparison of factors controlling stream metabolism. Freshwater Biology 46, 1503-1517 (2001).

4. Raymond, P. A. \& Hopkinson, C. S. Ecosystem modulation of dissolved carbon age in a temperate marsh-dominated estuary. Ecosystems 6, 694-705 (2003).

5. Raymond, P. A. \& Bauer, J. E. Riverine export of aged terrestrial organic matter to the North Atlantic Ocean. Nature 409, 497-500 (2001).

6. Jones, J. B. \& Mulholland, P. J. Carbon dioxide variation in a hardwood forest stream: An integrative measure of whole catchment soil respiration. Ecosystems 1, 183196 (1998).

7. Quay, P. D. et al. Carbon cycling in the Amazon River: Implications from the

${ }^{13} \mathrm{C}$ compositions of particles and solutes. Limnology and Oceanography 37, 857-871 (1992).

8. Devol, A. H. \& Hedges, J. I. in The Biogeochemistry of the Amazon Basin (eds. McClain, M. E., Victoria, R. L. \& Richey, J. E.) 275-306 (Oxford University Press, New York, 2001).

9. Hedges, J. I. et al. Organic carbon-14 in the Amazon River system. Science 231, 1129-1131 (1986).

10. Clark, I. \& Fritz, P. Environmental Isotopes in Hydrogeology (Lewis Publishers, Boca Raton, 1997). 
11. Stuiver, M. \& Polach, H. A. Discussion: Reporting of ${ }^{14} \mathrm{C}$ data. Radiocarbon 19, 355-363 (1977).

12. Levin, I. \& Hesshaimer, V. Radiocarbon -- A unique tracer of global carbon cycle dynamics. Radiocarbon 42, 69-80 (2000).

13. Randerson, J. T., Enting, I. G., Schuur, E. A. G., Caldeira, K. \& Fung, I. Y. Seasonal and latitudinal variability of troposphere $\Delta^{14} \mathrm{CO}_{2}$ : Post bomb contributions from fossil fuels, oceans, the stratosphere, and the terrestrial biosphere. Global Biogeochemical Cycles 16, 1112, doi:10.1029/2002GB001876 (2002).

14. Levin, I. \& Kromer, B. The tropospheric ${ }^{14} \mathrm{CO}_{2}$ level in mid-latitudes of the Northern Hemisphere (1959-2003). Radiocarbon 46, 1261-1272 (2004).

15. Stallard, R. F. \& Edmond, J. M. Geochemistry of the Amazon. 2. The influence of geology and weathering environment on the dissolved load. Journal of Geophysical Research 88, 9671-9688 (1983).

16. Melack, J. M. \& Forsberg, B. R. in The Biogeochemistry of the Amazon Basin (eds. McClain, M. E., Victoria, R. L. \& Richey, J. E.) 235-274 (Oxford University Press, New York, 2001).

17. Kerrick, D. M. Present and past nonanthropogenic $\mathrm{CO}_{2}$ degassing from the solid earth. Reviews of Geophysics 39, 565-585 (2001).

18. Körner, C., Farquhar, G. D. \& Wong, S. C. Carbon isotope discrimination by plants follows latitudinal and altitudinal trends. Oecologia 88, 30-40 (1991).

19. Hedges, J. I. et al. Organic matter in Bolivian tributaries of the Amazon River: A comparison to the lower mainstem. Limnology and Oceanography 45, 1449-1466 (2000).

20. Aufdenkampe, A. K., Hedges, J. I., Richey, J. E., Krusche, A. V. \& Llerena, C. A. Sorptive fractionation of dissolved organic nitrogen and amino acids onto fine 
sediments within the Amazon Basin. Limnology and Oceanography 46, 1921-1935 (2001).

21. Gibbs, R. J. The geochemistry of the Amazon River system: Part I. The factors that control the salinity and the composition and concentration of the suspended solids. Geological Society of America Bulletin 78, 1203-1232 (1967).

22. Trumbore, S. E. Age of soil organic matter and soil respiration: Radiocarbon constraints on belowground C dynamics. Ecological Applications 10, 399-411 (2000).

23. Grimm, N. B. et al. Merging aquatic and terrestrial perspectives of nutrient biogeochemistry. Oecologia 442, 485-501 (2003).

24. Bernardes, M. C. et al. Riverine organic matter composition as a function of land use changes, Southwest Amazon. Ecological Applications 14, S263-S279 (2004).

25. Aufdenkampe, A. K. et al. Organic matter in the Peruvian headwaters of the Amazon: A comparison to Bolivian tributaries and the lowland Amazon mainstem. Organic Geochemistry (in press).

26. Vogel, J. S., Nelson, D. E. \& Southon, J. R. ${ }^{14} \mathrm{C}$ background levels in an accelerator mass spectrometry system. Radiocarbon 29, 323-333 (1987).

27. Zhang, J., Quay, P. D. \& Wilbur, D. O. Carbon isotope fractionation during gaswater exchange and dissolution of $\mathrm{CO}_{2}$. Geochimica et Cosmochimica Acta 59, 107-114 (1995).

28. Gesch, D. B., Verdin, K. L. \& Greenlee, S. K. New land surface digital elevation model covers the Earth. EOS 80, 70-71 (1999).

29. Mayorga, E., Logsdon, M. G., Ballester, M. V. R. \& Richey, J. E. Estimating cell-to-cell land surface flow paths from digital channel networks, with an application to the Amazon basin. Journal of Hydrology (in press). 
30. Hedges, J. I. et al. Compositions and fluxes of particulate organic material in the Amazon River. Limnology and Oceanography 31, 717-738 (1986).

Acknowledgments. We thank staff at the Lawrence Livermore National Laboratory Center for Accelerator Mass Spectrometry (LLNL CAMS) for assistance with radiocarbon analyses; C. Llerena (Peru), B. Forsberg (Brazil), L. Maurice-Bourgoin (France-IRD), and J. Quintanilla (Bolivia) for invaluable assistance with field campaigns; and I. Levin (Heidelberg) for assistance with atmospheric ${ }^{14} \mathrm{CO}_{2}$ data. This work was funded by a LLNL CAMS Minigrant, US NSF DEB, NASA EOS and LBA projects, the Brazilian FAPESP agency, and a NASA ESS graduate fellowship to E.M. This work was performed, in part, under the auspices of the U.S. Department of Energy by University of California, Lawrence Livermore National Laboratory under contract W-7405-Eng-48. We dedicate this paper to the memory of J.I. Hedges.

Supplementary Information accompanies the paper on www.nature.com/nature.

Competing interests statement. The authors declare that they have no competing financial interests. 
Table 1. Summary of ${ }^{14} \mathrm{C}$ and ${ }^{13} \mathrm{C}$ isotopic composition for each carbon fraction, by topographical site category. All carbonate-free sites are in the lowlands.

\begin{tabular}{|c|c|c|c|c|c|c|c|c|}
\hline \multirow{2}{*}{$\begin{array}{l}\text { Site } \\
\text { Category }\end{array}$} & \multicolumn{2}{|c|}{$\mathrm{CO}_{2}$} & \multicolumn{2}{|c|}{ DOC } & \multicolumn{2}{|c|}{ FPOC } & \multicolumn{2}{|c|}{ CPOC } \\
\hline & $\Delta^{14} \mathrm{C}$ & $\delta^{13} \mathrm{C}$ & $\Delta^{14} C$ & $\delta^{13} \mathrm{C}$ & $\Delta^{14} \mathrm{C}$ & $\delta^{13} \mathrm{C}$ & $\Delta^{14} \mathrm{C}$ & $\delta^{13} \mathrm{C}$ \\
\hline Mountain & $-240 \pm 233(14)$ & $-12.9 \pm 2.2$ & $94 \pm 176(6)$ & $-26.0 \pm 3.0$ & $-202 \pm 198(8)$ & $-25.7 \pm 1.7$ & $-39 \pm 146(9)$ & $-27.0 \pm 1.6$ \\
\hline Mixed & $-14 \pm 99(11)$ & $-19.4 \pm 1.2$ & $196 \pm 59(9)$ & $-29.0 \pm 0.6$ & $-135 \pm 141(10)$ & $-28.2 \pm 0.9$ & $-124 \pm 66(9)$ & $-27.7 \pm 0.9$ \\
\hline Lowland & $89 \pm 44(43)$ & $-20.1 \pm 3.6$ & $177 \pm 64(15)$ & $-29.0 \pm 0.9$ & $90 \pm 55(10)$ & $-29.8 \pm 1.8$ & $112 \pm 83(4)$ & $-28.5 \pm 0.7$ \\
\hline \multicolumn{9}{|l|}{ Carbonate- } \\
\hline free & $98 \pm 20(38)$ & $-19.8 \pm 3.7$ & $175 \pm 67(11)$ & $-29.1 \pm 0.7$ & $129 \pm 10(6)$ & $-29.2 \pm 2.1$ & $121 \pm 100(3)$ & $-28.4 \pm 0.9$ \\
\hline
\end{tabular}

Data are reported as mean \pm standard deviation (number of samples), in per mil $(\% \circ)$. The number of samples for ${ }^{13} \mathrm{C}$ is the same as that shown for ${ }^{14} \mathrm{C}$. $\delta^{13} \mathrm{C}$-DIC summary values are $4.9 \pm 2.7 \%$ o (mountain), $-14.2 \pm 2.9 \%$ (mixed), $-17.0 \pm 5.9 \%$ (lowland), and $-17.1 \pm 6.2 \%$ (carbonatefree).

Figure 1. Amazon basin and river sites sampled for carbon isotopes. We used GTOPO30 elevation ${ }^{28}$ and a regional river network dataset ${ }^{29}$ to categorize each site by topography according to the percent of the drainage area above 1000 meter elevation: mountain (diamond), $\geq 50 \%$ (16 sites); mixed (square), $\geq 10 \%$ (11 sites); and lowland (circle), < 10\% (33 sites). Mountain sites are found only in the Andean Cordillera, while mixed sites are large rivers draining both mountain and lowland areas. Site numbers are displayed. Distribution of sites by drainage area (river size) and mean basin elevation is inset. Additional information is in Supplementary Table S1.

Figure 2. Distribution of ${ }^{14} \mathrm{C}$ and ${ }^{13} \mathrm{C}$ isotopes. Lower $\Delta{ }^{14} \mathrm{C}$ values indicate older carbon. Symbol shapes as in as in Fig. 1; Red (shaded), blue, orange, and 
green symbols represent $\mathrm{CO}_{2}, \mathrm{DOC}, \mathrm{FPOC}$, and $\mathrm{CPOC}$ respectively. Isotopic ranges of carbon sources are shown by grey boxes. Plant $\delta^{13} \mathrm{C}$ ranges from $32 \%$ to $-26 \%$ for lowland plant material fixed via the $\mathrm{C}_{3}$ photosynthetic pathway dominant among plants, to $-16 \%$ to $-12 \%$ for tropical $\mathrm{C}_{4}$ grasses $^{24,30}$. Phytoplankton take up $\mathrm{H}_{2} \mathrm{CO}_{3}$ and impose ${ }^{13} \mathrm{C}$ fractionations of $\sim-20 \%$, leading to biomass $\delta^{13} \mathrm{C}$ values of -32 to $-45 \%$ in mixed and lowland rivers ${ }^{8,10,30}$, beyond the range found in our lowland $\mathrm{OC}$ and $\mathrm{CO}_{2}$ observations. Carbonate rocks and $\mathrm{CO}_{2}$ from solid earth degassing are ${ }^{14} \mathrm{C}$-free $\left(\Delta^{14} \mathrm{C}=-1000 \%\right.$ ) (ref. 10$) . \delta^{13} \mathrm{C}$ of carbonate rocks is $\sim 0 \%$; degassed $\mathrm{CO}_{2}$ ranges from $-6 \%$ for volcanic to $10 \%$ for metamorphic sources ${ }^{10}$. The carbonate weathering region represents $\mathrm{CO}_{2}$ in equilibrium with $\mathrm{HCO}_{3}{ }^{-}$resulting from weathering by $\mathrm{CO}_{2}$ derived from respired, contemporary $\mathrm{C}_{3}$ or $\mathrm{C}_{4}$ plant material ${ }^{10}$.

Figure 3. Temporal evolution of ${ }^{14} \mathrm{C}-\mathrm{CO}_{2}$ at four lowland sites from mid-to-large rivers in the Ji-Parana basin and Rio Negro. Legend is as in Fig. 1. These sites drain continental shields and were analysed for ${ }^{14} \mathrm{C}$-DIC $2-3$ times between 1996 and 2003. 


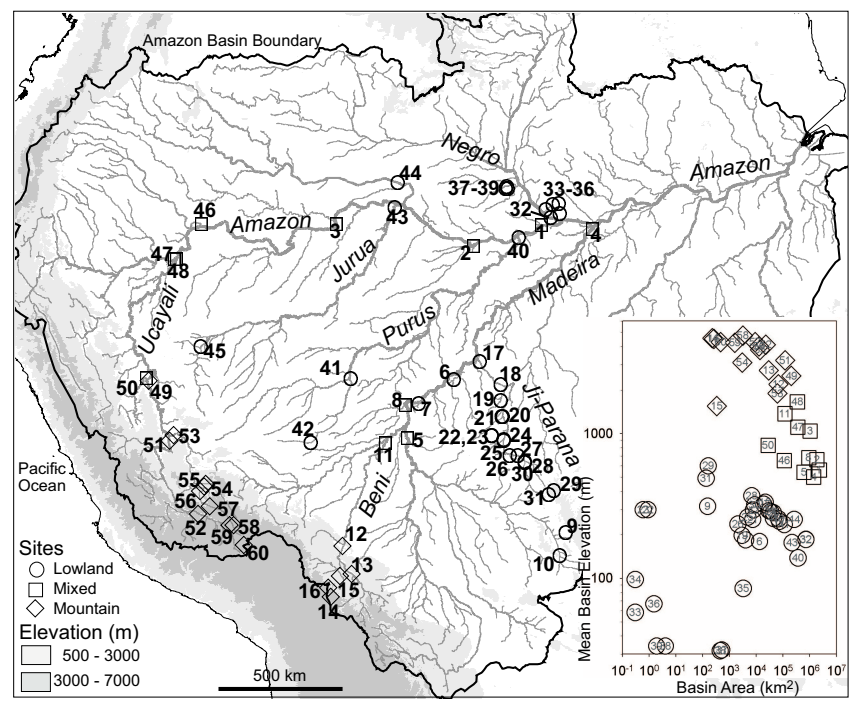




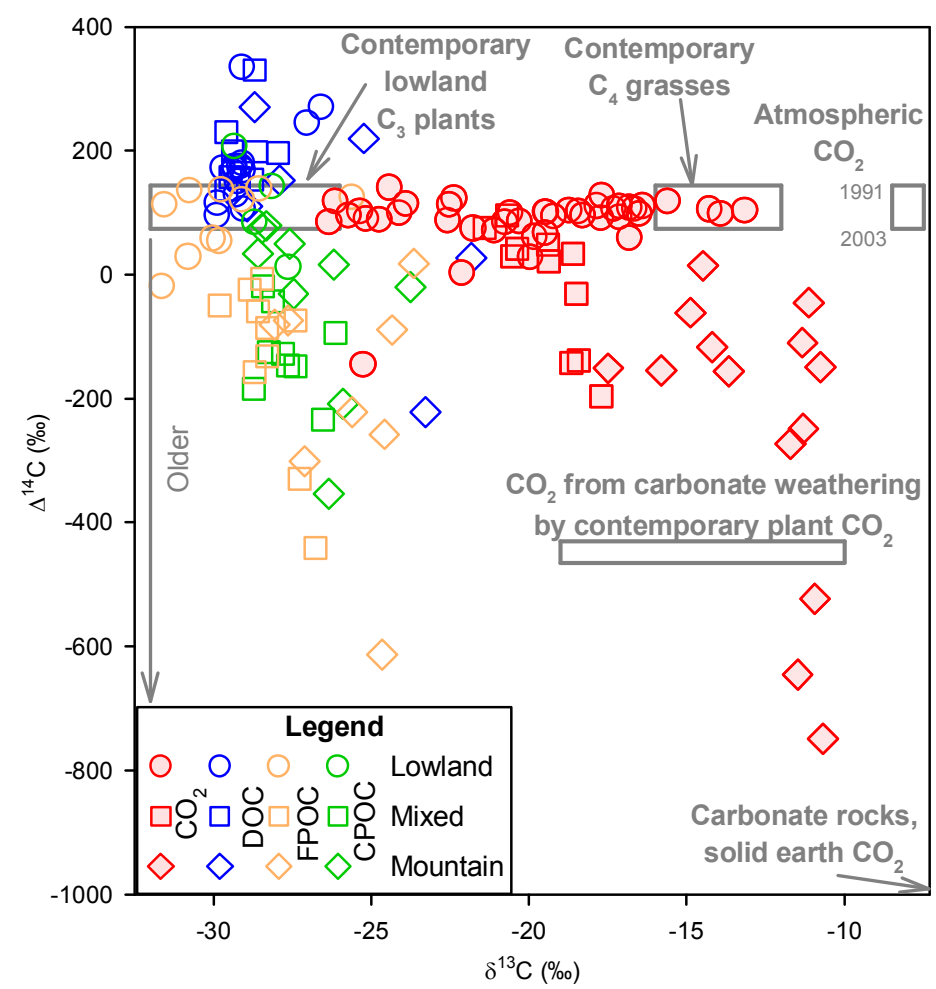




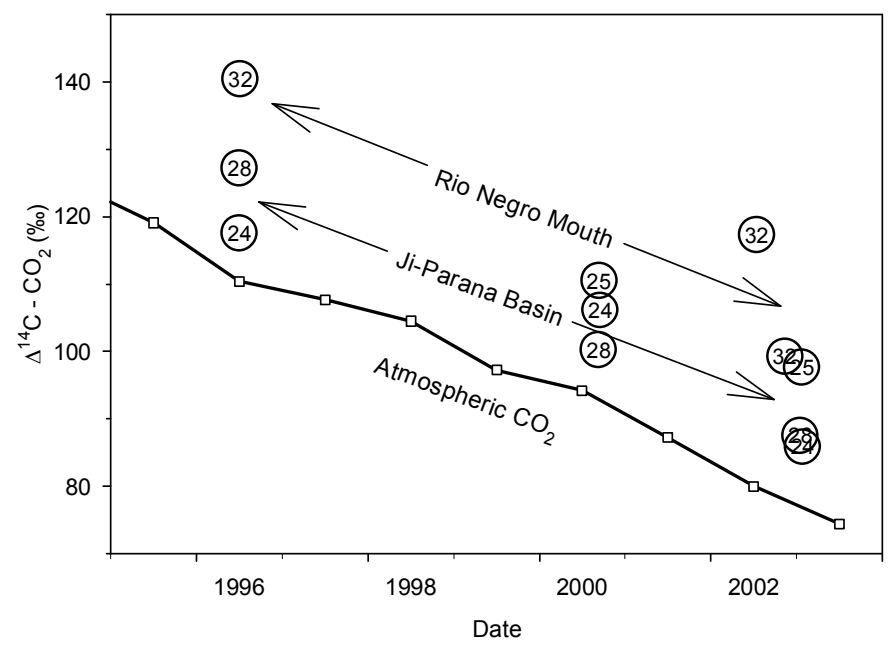




\title{
Young organic matter as a source of carbon dioxide outgassing from Amazonian rivers
}

\author{
Emilio Mayorga ${ }^{1}$, Anthony K. Aufdenkampe ${ }^{2}$, Caroline A. Masiello ${ }^{3}$, Alex V. \\ Krusche $^{4}$, John I. Hedges ${ }^{1, \dagger}$, Paul D. Quay ${ }^{1}$, Jeffrey E. Richey ${ }^{1} \&$ Thomas A. Brown ${ }^{5}$ \\ ${ }^{1}$ School of Oceanography, University of Washington, Seattle, WA 98195, USA \\ ${ }^{2}$ Stroud Water Research Center, Avondale, PA 19311, USA \\ ${ }^{3}$ Department of Earth Science, Rice University, Houston, TX 77005, USA \\ ${ }^{4}$ Laboratório de Ecologia Isotópica, CENA-USP, 13400-970 Piracicaba SP, Brazil \\ ${ }^{5}$ Center for Accelerator Mass Spectrometry, Lawrence Livermore National Laboratory, \\ Livermore, CA 94551, USA
}

E.M. and A.K.A. contributed equally to this work.

Correspondence and request for materials should be addressed to E.M. (emiliomayorga@alum.mit.edu).

${ }^{\dagger}$ Deceased.

\section{Supplementary Discussion}

Use of calculated $\delta^{13} \mathrm{C}$ of $\mathrm{CO}_{2}$ gas versus measured $\delta^{13} \mathrm{C}$ of DIC. There are two approaches to using stable isotopes to constrain sources contributing to pool - the mass balance approach, which requires an accounting of all fluxes and all species in a pool, and the steady-state approach, which only requires an accounting of the fluxes in and out of a pool. We use the latter approach in this paper, for reasons that can be illustrated by a thought experiment. Imagine two bottles of water at $25^{\circ} \mathrm{C}$, each being sparged with bubbles of $\mathrm{CO}_{2}$ with a $\delta^{13} \mathrm{C}=-27.0 \%$. Bottle \#1 is buffered to have a final $\mathrm{pH}$ of 3.8 at equilibrium, and the other a final $\mathrm{pH}$ of 8.7. These represent the extremes 
of $\mathrm{pH}$ values observed in our Amazon data set (Table S2). Dissolved $\mathrm{CO}_{2}$ will speciate into bicarbonate $\left(\mathrm{HCO}_{3}{ }^{-}\right)$and carbonate $\left(\mathrm{CO}_{3}{ }^{2-}\right)$ ions as a function of $\mathrm{pH}$, with the following enrichment factors $(\varepsilon)$ for these reactions ${ }^{10,27}$ :

$$
\begin{array}{ll}
\mathrm{CO}_{2}(\mathrm{~g})+\mathrm{H}_{2} \mathrm{O} \leftrightarrow \mathrm{H}_{2} \mathrm{CO}_{3} & \varepsilon=-1.2 \% \mathrm{o} \\
\mathrm{H}_{2} \mathrm{CO}_{3} \leftrightarrow \mathrm{H}^{+}+\mathrm{HCO}_{3}{ }^{-} & \varepsilon=+9.1 \% \mathrm{o} \\
\mathrm{HCO}_{3}{ }^{-} \leftrightarrow \mathrm{H}^{+}+\mathrm{CO}_{3}{ }^{2-} & \varepsilon=-2.0 \% \mathrm{o}
\end{array}
$$

Partitioning of DIC into each species is calculated using standard, temperaturedependent equilibrium constants ${ }^{10}$. In bottle $\# 1,99.7 \%$ of the DIC will be in the form of $\mathrm{H}_{2} \mathrm{CO}_{3}$, whereas in bottle $\# 2,97.3 \%$ of the DIC is found as $\mathrm{HCO}_{3}{ }^{-}$. At steady state the $\delta^{13} \mathrm{C}$ of DIC in these two bottles will be $-28.2 \%$ and $-19.2 \%$, respectively. $\mathrm{pH}$ has a large impact on steady-state $\delta^{13} \mathrm{C}$-DIC beyond the $\delta^{13} \mathrm{C}$ imprint of the $\mathrm{CO}_{2}$ source alone. Whereas steady state simply requires that the $\delta^{13} \mathrm{C}$ of outgassing $\mathrm{CO}_{2}$ in each bottle must be equal to the $\delta^{13} \mathrm{C}$ of the $\mathrm{CO}_{2}$ source $\left(-27.0 \%\right.$ ), relating the $\delta^{13} \mathrm{C}$ of DIC to that of the $\mathrm{CO}_{2}$ source can not be accomplished casually without the use of equilibrium constant expressions and isotopic enrichment factors.

An analogous steady-state approach is useful in all aquatic systems where DIC turns over rapidly due to high $\mathrm{CO}_{2}$ fluxes. For instance, in rivers of the carbonate-free Amazon lowlands (where piston velocity $(\mathrm{K})>2 \mathrm{~m} / \mathrm{d}$ (ref. 1), typically $\mathrm{pCO}_{2}>5000$ ppm and DIC $<500 \mu \mathrm{M}$ (Table S2), and assuming river depth $<10 \mathrm{~m}$ ) turnover time is less than 13 days and in most cases only 2-4 days, which is short relative to the large river lengths and corresponding long water residence times in the river system ${ }^{29}$. In small streams where $\mathrm{pCO}_{2}$ is greater and water depths are shallower, turnover times $<1$ day are likely. Other evidence for quasi-steady state is the relatively small downstream rate of change of DIC isotopes in all carbonate-free rivers except the Ji-Parana 
headwaters (sites 28-31), where vegetation transitions occur. Previous studies in the highly supersaturated Amazon mainstem have also indicated the existence of a quasisteady state between evasion and in situ respiration with respect to $\mathrm{CO}_{2}$ and ${ }^{13} \mathrm{CO}_{2}$ fluxes ${ }^{7,8} ; \delta^{13} \mathrm{C}_{\text {of }} \mathrm{CO}_{2}$ evading from the river is the same as that produced during respiration ${ }^{7}$, while tributary DIC and ${ }^{13} \mathrm{C}$-DIC inputs account for mainstem downstream changes $^{7,8}$. Together the evidence suggests that dynamic equilibrium or quasi-steady state between evasion and respiration with respect to $\mathrm{CO}_{2},{ }^{13} \mathrm{CO}_{2}$, and ${ }^{14} \mathrm{CO}_{2}$ is a reasonable first-order assumption at sites not influenced by continuing dissolution of carbonate minerals, where data to construct complete mass balances are not available. The implication is that at these sites, the $\delta^{13} \mathrm{C}$ and $\Delta^{14} \mathrm{C}$ of evaded $\mathrm{CO}_{2}$ gas should be equivalent to the isotopic signature of respired OC.

In systems where carbonate mineral dissolution is active or DIC turnover times are low, this steady state approach may not be valid as the river approximates a closed system. For instance, using values for the Hudson River from Cole and Caraco $^{2}$ (where $\mathrm{K}=0.8 \mathrm{~m} / \mathrm{d}$ and $\mathrm{pCO}_{2}<2000 \mathrm{ppm}$, and assuming depth $=10 \mathrm{~m}$ ), the turnover time of DIC is $>220$ days. Therefore, these systems are far from steady state and are likely still degassing the initial DIC resulting from carbonate mineral dissolution. In this case, the $\delta^{13} \mathrm{C}$ of DIC is determined by the mass balance of the multiple sources and sinks to DIC (carbonate minerals $+\mathrm{CO}_{2}$ from respiration $-\mathrm{CO}_{2}$ evasion), and $\mathrm{pH}$ controls the $\delta^{13} \mathrm{C}$ of $\mathrm{CO}_{2}$ evading from the river relative to that of DIC.

$\mathrm{CO}_{2}$ and organic carbon sources. To assess the influence of carbonate weathering on river geochemistry, we examined the inorganic solute composition at each site relative to guidelines suggested by Stallard and Edmond ${ }^{15}$ (Fig. S1). This approach identifies as carbonate-influenced all mountain and mixed sites, and five lowland sites (Figs. $1 \&$ S1, sites 10, 41, 42, $43 \& 45$ ). The remaining 25 lowland sites (38 samples, including those presented in Fig. 3) have little potential for direct 
carbonate mineral contributions to DIC, and contain $\mathrm{CO}_{2}$ that is predominantly contemporary (Table 1, Fig. 2).

$\mathrm{CO}_{2}$ in carbonate-free rivers is generally isotopically distinct from the associated OC fractions (DOC, FPOC, and CPOC; Fig. 2). A $\Delta^{14} \mathrm{C}$ comparison of $\mathrm{CO}_{2}$ against OC fractions at the 5 carbonate-free sites where $\mathrm{CO}_{2}$ and at least two $\mathrm{OC}$ fractions were measured concurrently (Table S3, 1996 samples from sites 6, 24, 28, 32 \& 40) yields mixed results. $\mathrm{CO}_{2}$ is considerably younger than DOC (the primary OC fraction) in 2 out of 3 observations, but is undistinguishable from FPOC $\left(\Delta^{14} \mathrm{C}-\mathrm{CO}_{2}=122 \pm 15 \%\right.$ vs. $\Delta \Delta^{14} \mathrm{C}-\mathrm{FPOC}=130 \pm 11 \%$, $\left.\mathrm{n}=5\right)$; in these rivers, FPOC on average makes up only $1 / 4$ of total OC and is characterized by low fine suspended sediment (FSS) concentrations and high \%weight (Table S2). CPOC is also older than $\mathrm{CO}_{2}$ but makes up a very small fraction of total OC.

While the above $\Delta^{14} \mathrm{C}$ comparison between $\mathrm{CO}_{2}$ and $\mathrm{OC}$ is limited, it can be extended first with samples from the Rio Negro mouth and several small Negro streams where DIC and DOC samples were collected 7 years apart (2002 vs. 1995, sites 32 39). OC in these clear and blackwater rivers is strongly dominated by DOC (Table S2). Comparing $\Delta^{14} \mathrm{C}$ offsets against sampling year atmospheric $\Delta^{14} \mathrm{C}-\mathrm{CO}_{2}$, the DOC offset $(63 \pm 66 \%, n=8)$ is 3 times the $\mathrm{CO}_{2}$ offset $(19 \pm 12 \%, n=8)$. While the difference in the means is not statistically significant $(\mathrm{p}=0.0850$, Student's t-test for independent samples), high DOC variance is largely the result of one outlier with an even larger atmospheric offset of $217 \%$; excluding this value yields a DOC offset of $41 \pm 25 \%$ and a marginally significant difference with respect to the $\mathrm{CO}_{2}$ offset $(\mathrm{p}=0.0440)$. Second, $\Delta^{14} \mathrm{C}-\mathrm{OC}$ in lowland samples potentially influenced by carbonates (Table S3, 1996 samples from sites $10,41,43 \& 45)$ is characterised by a similar DOC atmospheric $\Delta^{14} \mathrm{C}$ offset of $73 \pm 64 \%$ o $(n=4)$. The FPOC offset $(-79 \pm 35 \%$ o, $n=4)$ indicates substantial aging at these sites which, except for the Guapore (site 10), are characterised by high FSS and 
low \%weight FPOC values comparable to the Amazon mainstem ${ }^{30}$ (Table S2). Therefore, while scatter is substantial, DOC - the dominant lowland OC fraction - is generally just under a decade in age; in carbonate-free lowland systems, DOC is older than $\mathrm{CO}_{2}$. FPOC represents a more heterogeneous but less important component of total OC in such systems.

Carbonate-free lowland $\delta^{13} \mathrm{C}-\mathrm{CO}_{2}$ is generally enriched with respect to all OC fractions (Tables $1 \&$ S3, Fig. 2). The separation for coincident samples is over $8 \%$, with $\delta^{13} \mathrm{C}-\mathrm{CO}_{2}=-20.1 \pm 3.5 \%(\mathrm{n}=5), \delta^{13} \mathrm{C}-\mathrm{DOC}=-28.7 \pm 1.5 \%{ }_{0}(\mathrm{n}=3), \delta^{13} \mathrm{C}-\mathrm{FPOC}=-$ $29.2 \pm 2.3 \%$ o $(n=5)$, and $\delta^{13} \mathrm{C}-\mathrm{CPOC}=-28.4 \pm 0.9 \%$ o $(n=3)$. For Rio Negro basin DIC and DOC samples collected 7 years apart, $\delta^{13} \mathrm{C}-\mathrm{CO}_{2}=-25.2 \pm 0.9 \%$ o $(\mathrm{n}=8)$ and $\delta^{13} \mathrm{C}-\mathrm{DOC}=-$ $29.2 \pm 0.1 \%$ o $(\mathrm{n}=8) .{ }^{13} \mathrm{C}$ separation between $\mathrm{CO}_{2}$ and $\mathrm{OC}$ is smallest in the Rio Negro basin, where $\mathrm{C}_{4}$ grasses are rare, and largest in the Ji-Parana basin, where deforestation has led to widespread replacement of forest by $\mathrm{C}_{4}$ pastures, even along stream corridors $^{24}$. Lowland $\delta^{13} \mathrm{C}-\mathrm{OC}$ observations in this study are similar to those obtained previously $^{7,24,30}$.

Influence of carbonate weathering in mountain and mixed sites. Mountain and mixed river sites contain older dissolved $\mathrm{CO}_{2}\left(\Delta^{14} \mathrm{C}=96\right.$ to $-749 \%$, Fig. 2) resulting in large part from carbonate mineral dissolution involving the chemical reaction $\mathrm{CaCO}_{3}(\mathrm{~s})+\mathrm{H}_{2} \mathrm{CO}_{3}(\mathrm{aq})=\mathrm{Ca}^{2+}(\mathrm{aq})+2 \mathrm{HCO}_{3}{ }^{-}(\mathrm{aq})$. Although the dissolution of carbonates increases DIC, it also increases $\mathrm{pH}$, with the net result of decreasing dissolved free $\mathrm{CO}_{2}$ concentrations and reducing evasion fluxes. Thus, while carbonate dissolution has a large impact on the isotopic signature of evaded $\mathrm{CO}_{2}$, it can not be the main driver of outgassing. Observed $\mathrm{CO}_{2}$ supersaturation must be maintained by a continuous flux of $\mathrm{CO}_{2}$ from $\mathrm{OC}$ respiration or other $\mathrm{CO}_{2}$ sources. These fluxes and the resulting $\mathrm{CO}_{2}$ outgassing will gradually flush out DIC originally exported from carbonates in terrestrial settings, replacing its isotopic signature with that of the new 
$\mathrm{CO}_{2}$ source. Indeed, a $\mathrm{CO}_{2}$ trend of increasing $\Delta^{14} \mathrm{C}$ and decreasing $\delta^{13} \mathrm{C}$ is observed from the Andes down to the mainstem Amazon (Fig. 2). However, this flushing is not rapid. In the mainstem of the forested middle and lower Ucayali basin, major ion geochemistry indicates that carbonate dissolution remains a dominant source of DIC from the Andean foothills to the sedimentary lowlands nearly $2000 \mathrm{~km}_{\text {downstream }}{ }^{15}$ (from site 56 to site 48 , Figs. $1 \& \mathrm{~S} 1$ ); consequently, $\Delta^{14} \mathrm{C}-\mathrm{CO}_{2}$ remains substantially depleted (-138\%o at downstream site 48$)$ despite likely high respiratory inputs that steadily increase $\mathrm{CO}_{2}$ concentrations from 560 to $3150 \mathrm{ppm}$ (Table S2). Over the next $2000 \mathrm{~km}$ downstream (from sites 47 and 48 to site 1) carbonate sediments become less prevalent and respired $\mathrm{CO}_{2}$ gradually flushes out aged DIC, as observed in $\Delta^{14} \mathrm{C}-\mathrm{CO}_{2}$ increases from approximately $-167 \%$ to a mean of $49 \%$, still below contemporary atmospheric $\Delta^{14} \mathrm{C}$ levels. Therefore, all along the middle-lower Ucayali and westerncentral mainstem, inputs of young $\mathrm{CO}_{2}$ from in situ respiration and tributary inflow drive large gas evasion fluxes of aged $\mathrm{CO}_{2}$ originating from carbonate dissolution; partitioning of DIC from $\mathrm{HCO}_{3}{ }^{-}$to $\mathrm{H}_{2} \mathrm{CO}_{3}$ due to a lowering of $\mathrm{pH}$ (e.g., at the confluence of blackwater and whitewater rivers) may be a significant $\mathrm{CO}_{2}$ source only near the central mainstem (Table S2).

Specific site references from the discussion. Limitations on the length of the manuscript prevented the inclusion of relevant site ID references for all discussions. This section collects such references to facilitate data interpretation. In Figure 3, JiParana sites include site IDs $24,25 \& 28$, while the Rio Negro mouth is site 32 . The second, smaller group of observations in carbonate-free lowland sites referred to in the text includes 3 streams (sites 22, $29 \& 31$ ) and 2 mid-sized rivers (sites $6 \& 7$ ). Submerged grasses were present only in small Ji-Parana streams, at sites $22 \& 23$. In the central Amazon mainstem site (site 1), $\Delta^{14} \mathrm{C}-\mathrm{CO}_{2}$ reaches approximately $49 \%$, still below atmospheric levels. The Vilcanota river in the arid mountain headwaters of the 
Ucayali, in Peru, includes three sites (sites 57, 58 \& 59) highly depleted in ${ }^{14} \mathrm{C}$ that appear to be influenced by solid-earth degassing. 


\section{Supplementary Tables}

Supplementary Table S1. Site and drainage area characterisation. Latitude (Lat) and Longitude (Lon) are in decimal degrees. A few sites represent aggregated data from distinct sites in relative proximity. Site numbers 17 - 31 are in the Ji-Parana basin (see Fig. 1) and their site names correspond to codes used in previous studies ${ }^{24}$. Continued on next page.

\begin{tabular}{|c|c|c|c|c|c|c|c|c|}
\hline \multirow[b]{2}{*}{ Site \# } & \multirow[b]{2}{*}{ River } & \multirow[b]{2}{*}{ Site Name } & \multirow[b]{2}{*}{$\begin{array}{c}\text { Lat } \\
{ }^{\circ} \mathrm{S}\end{array}$} & \multirow[b]{2}{*}{$\begin{array}{l}\text { Lon } \\
{ }^{\circ} \mathrm{W}\end{array}$} & \multirow[b]{2}{*}{$\begin{array}{l}\text { Area } \\
\mathrm{km}^{2}\end{array}$} & \multicolumn{3}{|c|}{ Elevation } \\
\hline & & & & & & $\begin{array}{c}\text { Site } \\
\mathrm{M}\end{array}$ & $\begin{array}{c}\text { Basin Mean } \\
\mathrm{m}\end{array}$ & $\begin{array}{c}\%> \\
1000 \mathrm{~m}\end{array}$ \\
\hline & & & & owland & & & & \\
\hline 6 & Candeias & Candeias & 8.766 & 63.708 & 13,200 & 77 & 179 & 0.2 \\
\hline 7 & Azul & Azul & 9.627 & 64.942 & 4,030 & 103 & 184 & 0.0 \\
\hline 9 & Novo & Novo & 14.172 & 59.742 & 150 & 295 & 314 & 0.0 \\
\hline 10 & Guaporé & Vila Bela & 14.993 & 59.958 & 21,660 & 193 & 335 & 0.0 \\
\hline 17 & Ji-Paraná & JIP-5 & 8.147 & 62.787 & 73,410 & 69 & 246 & 0.0 \\
\hline 18 & Ji-Paraná & JIP-4 & 8.947 & 62.057 & 67,640 & 91 & 257 & 0.0 \\
\hline 19 & Machadinho & MAC & 9.507 & 62.047 & 2,970 & 198 & 198 & 0.0 \\
\hline 20 & Ji-Paraná & JIP-3 & 10.092 & 61.977 & 43,580 & 181 & 284 & 0.0 \\
\hline 21 & Jarú & JARU & 10.102 & 61.996 & 7,410 & 180 & 254 & 0.0 \\
\hline 22 & Boa Vista & NS1 & 10.757 & 62.368 & $<10$ & 296 & 297 & 0.0 \\
\hline 23 & Boa Vista & $\mathrm{NS} 2$ & 10.753 & 62.372 & $<10$ & 296 & 298 & 0.0 \\
\hline 24 & Ji-Paraná & JIP-2 & 10.937 & 61.957 & 29,770 & 192 & 293 & 0.0 \\
\hline 25 & Urupá & URUPA & 10.902 & 61.962 & 4,820 & 191 & 264 & 0.0 \\
\hline 26 & Rolim de Moura & ROLIM & 11.445 & 61.731 & 2,060 & 200 & 236 & 0.0 \\
\hline 27 & Ji-Paraná & JIP-1 & 11.452 & 61.463 & 19,170 & 200 & 325 & 0.0 \\
\hline 28 & Comemoração & COM-2 & 11.667 & 61.188 & 6,740 & 199 & 372 & 0.0 \\
\hline 29 & Comemoração & COM-1 & 12.718 & 60.173 & 160 & 594 & 598 & 0.0 \\
\hline 30 & Pimenta Bueno & PB-2 & 11.703 & 61.192 & 8,650 & 197 & 321 & 0.0 \\
\hline 31 & Pimenta Bueno & PB-1 & 12.847 & 60.343 & 130 & 495 & 491 & 0.0 \\
\hline 32 & Negro & Mouth & 3.063 & 60.302 & 716,770 & 29 & 185 & 1.1 \\
\hline 33 & Barro Branco & Reserva Ducke 1 & 2.932 & 59.978 & $<10$ & 59 & 58 & 0.0 \\
\hline 34 & Cabeça Branca & Reser. Campinas 1 & 2.582 & 60.022 & $<10$ & 99 & 98 & 0.0 \\
\hline 35 & Cueiras & Cueiras & 2.781 & 60.442 & 3,280 & 40 & 85 & 0.0 \\
\hline 36 & Asu & Reserva ZF2 1 & 2.608 & 60.216 & $<10$ & 67 & 67 & 0.0 \\
\hline 37 & Miratucu & Miratucu 4 & 1.963 & 61.848 & 520 & 34 & 32 & 0.0 \\
\hline 38 & Miratucu & Miratucu 3ag & 2.031 & 61.853 & 450 & 34 & 32 & 0.0 \\
\hline 39 & Cobra & Miratucu 2c & 2.027 & 61.813 & $<10$ & 34 & 34 & 0.0 \\
\hline 40 & Purus & Mouth & 3.747 & 61.433 & 362,900 & 32 & 138 & 0.0 \\
\hline 41 & Purus & Boca do Acre & 8.732 & 67.378 & 111,630 & 100 & 235 & 0.0 \\
\hline 42 & Acre & Brasileia & 11.002 & 68.764 & 7,820 & 250 & 296 & 0.0 \\
\hline 43 & Juruá & Mouth & 2.722 & 65.803 & 217,370 & 56 & 176 & 0.0 \\
\hline 44 & Japurá & Mouth & 1.817 & 65.683 & 260,010 & 55 & 255 & 3.4 \\
\hline 45 & Juruá & Cruzeiro do Sul & 7.622 & 72.637 & 43,960 & 188 & 259 & 0.0 \\
\hline
\end{tabular}


Supplementary Table S1 continued. Site and drainage area characterisation.

\begin{tabular}{|c|c|c|c|c|c|c|c|c|}
\hline \multirow[b]{2}{*}{ Site \# } & \multirow[b]{2}{*}{ River } & \multirow[b]{2}{*}{ Site Name } & \multirow[b]{2}{*}{$\begin{array}{l}\text { Lat } \\
{ }^{\circ} \mathrm{S}\end{array}$} & \multirow[b]{2}{*}{$\begin{array}{l}\text { Lon } \\
{ }^{\circ} \mathrm{W}\end{array}$} & \multirow[b]{2}{*}{$\begin{array}{l}\text { Area } \\
\mathrm{km}^{2}\end{array}$} & \multicolumn{3}{|c|}{ Elevation } \\
\hline & & & & & & $\begin{array}{c}\text { Site } \\
\mathrm{m}\end{array}$ & $\begin{array}{c}\text { Basin Mean } \\
m\end{array}$ & $\begin{array}{c}\%> \\
1000 \mathrm{~m}\end{array}$ \\
\hline & & & & Mixed & & & & \\
\hline 1 & Amazon & Manacapuru & 3.322 & 60.612 & $2,238,490$ & 28 & 560 & 13.4 \\
\hline 2 & Amazon & Itapeua & 4.053 & 63.017 & $1,818,270$ & 38 & 661 & 16.5 \\
\hline 3 & Amazon & Vargem Grande & 3.279 & 67.853 & $1,016,030$ & 70 & 1040 & 28.3 \\
\hline 4 & Madeira & Mouth & 3.450 & 58.798 & $1,381,590$ & 20 & 501 & 11.7 \\
\hline 5 & Mamoré & Guayaramerin & 10.848 & 65.347 & 601,470 & 120 & 541 & 12.5 \\
\hline 8 & Madeira & Madeira at Abunã & 9.677 & 65.417 & 906,120 & 127 & 681 & 17.8 \\
\hline 11 & Beni & Riberalta Arriba & 11.022 & 66.128 & 118,330 & 135 & 1372 & 46.2 \\
\hline 46 & Napo & Napo & 3.295 & 72.632 & 110,300 & 103 & 651 & 16.5 \\
\hline 47 & Marañón & Marañón & 4.528 & 73.568 & 358,170 & 113 & 1106 & 35.6 \\
\hline 48 & Ucayali & Ucayali & 4.522 & 73.487 & 341,200 & 112 & 1658 & 41.7 \\
\hline 50 & Pachitea & Mouth & 8.733 & 74.572 & 27,500 & 165 & 830 & 21.1 \\
\hline & & & & Mountain & & & & \\
\hline 12 & Beni & Rurrenabaque & 14.542 & 67.548 & 68,130 & 504 & 2191 & 79.0 \\
\hline 13 & Alto Beni & Sapecho & 15.617 & 67.330 & 29,590 & 608 & 2735 & 91.6 \\
\hline 14 & Achumani & Achumani & 16.472 & 68.063 & 230 & 3834 & 4565 & 100.0 \\
\hline 15 & Yara & Yara Caranavi & 15.777 & 67.588 & 340 & 1012 & 1550 & 84.4 \\
\hline 16 & Zongo & Zongo & 16.253 & 68.118 & 260 & 4555 & 4519 & 100.0 \\
\hline 49 & Ucayali & Ucayali at Pachitea & 8.783 & 74.553 & 205,520 & 165 & 2500 & 65.7 \\
\hline 51 & Tambo & Mouth & 10.787 & 73.773 & 121,290 & 286 & 3199 & 84.6 \\
\hline 52 & Apurimac & Cunyac & 13.567 & 72.589 & 22,760 & 2425 & 4105 & 100.0 \\
\hline 53 & Urubamba & Mouth & 10.757 & 73.712 & 61,070 & 288 & 1890 & 51.3 \\
\hline 54 & Yanatili & Quellouno & 12.602 & 72.533 & 3,020 & 1083 & 3089 & 98.3 \\
\hline 55 & Urubamba & Sahuayaoti & 12.646 & 72.538 & 13,920 & 824 & 3791 & 97.1 \\
\hline 56 & Urubamba & Quillabamba & 12.867 & 72.682 & 12,640 & 1142 & 4001 & 99.3 \\
\hline 57 & Urubamba & Pachar & 13.273 & 72.250 & 9,290 & 3106 & 4284 & 100.0 \\
\hline 58 & Salcca & Salcca & 14.102 & 71.422 & 3,190 & 3792 & 4743 & 100.0 \\
\hline 59 & Vilcanota & Tinta & 14.166 & 71.402 & 1,610 & 3571 & 4239 & 100.0 \\
\hline 60 & Lago Langui-Layo & Langui & 14.437 & 71.292 & 470 & 3877 & 4276 & 100.0 \\
\hline
\end{tabular}


Supplementary Table S2. Average geochemical properties for isotopic sampling sites, based on samples analysed for carbon isotopes. Data used for averages are based only on samples where a ${ }^{14} \mathrm{C}$ measurement was made. Continued on next page.

\begin{tabular}{|c|c|c|c|c|c|c|c|c|c|c|}
\hline Site \# & $\begin{array}{c}\text { Temperature } \\
{ }^{\circ} \mathrm{C}\end{array}$ & $\mathrm{pH}$ & $\begin{array}{c}\text { Alkalinity } \\
\mu \text { eq } L^{-1}\end{array}$ & $\begin{array}{c}\text { FSS } \\
\mathrm{mg} \mathrm{L}^{-1}\end{array}$ & $\begin{array}{c}\text { FPOC } \\
\% w t\end{array}$ & $\begin{array}{l}\mathrm{CO}_{2} \\
\mathrm{ppm}\end{array}$ & $\begin{array}{c}\text { DIC } \\
\mu \mathrm{mol} \mathrm{L}^{-1}\end{array}$ & $\begin{array}{c}\mathrm{DOC} \\
\mathrm{mg} \mathrm{L}^{-1}\end{array}$ & $\begin{array}{l}\text { FPOC } \\
\mathrm{mg} \mathrm{L}^{-1}\end{array}$ & $\begin{array}{l}\text { CPOC } \\
\mathrm{mg} \mathrm{L}^{-1}\end{array}$ \\
\hline \multicolumn{11}{|c|}{ Lowland } \\
\hline 6 & 25.4 & 5.92 & 98 & 19.1 & 7.13 & 7640 & 362 & 1.65 & 1.36 & 0.13 \\
\hline 7 & 25.1 & 5.94 & 77 & 14.7 & 9.91 & 5723 & 275 & 0.69 & 1.46 & \\
\hline 9 & 24.7 & 6.41 & 98 & 15.6 & 9.42 & 2476 & 184 & 0.68 & 1.47 & 0.93 \\
\hline 10 & 20.9 & 6.53 & 410 & 14.4 & 7.83 & 7837 & 681 & 3.41 & 1.13 & 0.19 \\
\hline 17 & 31.5 & 7.07 & 344 & 11.6 & & 2099 & 404 & 2.04 & & \\
\hline 18 & 30.1 & 7.13 & 205 & 7.6 & & 1063 & 236 & 2.57 & & \\
\hline 19 & 29.3 & 6.72 & 125 & 13.7 & & 1653 & 175 & 2.02 & & \\
\hline 20 & 30.1 & 7.39 & 243 & 17.0 & & 692 & 263 & 4.38 & & \\
\hline 21 & 29.6 & 7.45 & 532 & 14.4 & & 1312 & 570 & 4.75 & & \\
\hline 22 & 25.9 & 6.31 & 594 & 9.2 & & 10300 & & 5.98 & & \\
\hline 23 & 25.7 & 6.60 & 694 & 6.7 & & 7100 & & 4.36 & & \\
\hline 24 & 26.5 & 6.97 & 248 & 21.9 & 5.71 & 1525 & 300 & 2.78 & 0.88 & 0.10 \\
\hline 25 & 28.3 & 6.97 & 703 & 47.7 & & 3193 & 797 & 8.43 & & \\
\hline 26 & 29.6 & 7.44 & & 26.0 & & & & 2.68 & & \\
\hline 27 & 29.3 & 7.15 & 131 & 14.8 & & 643 & 150 & 2.43 & & \\
\hline 28 & 25.2 & 6.25 & 39 & 20.7 & 9.60 & 1346 & 85 & 2.49 & 1.12 & 0.18 \\
\hline 29 & 23.6 & 5.32 & 3 & 15.0 & 1.96 & 1872 & 70 & 1.60 & 0.53 & \\
\hline 30 & 28.9 & 7.12 & 197 & 14.0 & & 1031 & 229 & 4.02 & & \\
\hline 31 & 25.5 & 5.83 & 4 & 6.3 & & 565 & 25 & 1.36 & & \\
\hline 32 & 29.0 & 4.87 & 4 & 6.1 & 13.65 & 5197 & 184 & 10.24 & 0.61 & 0.01 \\
\hline 33 & 24.9 & 4.15 & 0 & & & 33550 & 1153 & 3.54 & & \\
\hline 34 & 25.5 & 3.94 & 0 & & & 26145 & 896 & 34.94 & & \\
\hline 35 & 30.3 & 3.84 & 0 & 7.7 & & 1205 & 41 & 6.74 & & \\
\hline 36 & 24.8 & 4.02 & 0 & & & 7375 & 252 & 9.11 & & \\
\hline 37 & & & & & & & & 7.02 & 0.77 & \\
\hline 38 & & & & & & & & 6.21 & 0.69 & \\
\hline 39 & & & & & & & & 6.09 & 0.39 & \\
\hline 40 & 26.9 & 5.94 & 135 & 16.3 & 5.91 & 10048 & 482 & 4.02 & 0.96 & 0.01 \\
\hline 41 & 26.4 & 7.68 & 2047 & 121.4 & 1.22 & 2757 & 2137 & 2.18 & 1.48 & 0.08 \\
\hline 42 & 23.7 & 7.99 & 1467 & 70.2 & 2.92 & 964 & 1494 & 2.15 & 2.05 & 0.07 \\
\hline 43 & 24.6 & 6.61 & 497 & 106.4 & 1.60 & 7824 & 767 & 3.50 & 1.70 & 0.05 \\
\hline 44 & 25.7 & 5.30 & 15 & 19.9 & 3.64 & 4920 & 185 & 3.48 & 0.73 & 0.07 \\
\hline 45 & 26.7 & 6.51 & 858 & 257.1 & 1.20 & 17173 & 1452 & 5.77 & 3.07 & \\
\hline
\end{tabular}


Supplementary Table S2 continued. Average geochemical properties for isotopic sampling sites, based on samples analysed for carbon isotopes.

\begin{tabular}{|c|c|c|c|c|c|c|c|c|c|c|}
\hline Site \# & $\begin{array}{c}\text { Temperature } \\
{ }^{\circ} \mathrm{C}\end{array}$ & $\mathrm{pH}$ & $\begin{array}{c}\text { Alkalinity } \\
\mu \text { eq } \mathrm{L}^{-1}\end{array}$ & $\begin{array}{c}\mathrm{FSS} \\
\mathrm{mg} \mathrm{L}^{-1}\end{array}$ & $\begin{array}{l}\text { FPOC } \\
\% w t\end{array}$ & $\begin{array}{l}\mathrm{CO}_{2} \\
\mathrm{ppm}\end{array}$ & $\begin{array}{c}\text { DIC } \\
\mu \mathrm{mol} \mathrm{L}^{-1}\end{array}$ & $\begin{array}{c}\mathrm{DOC} \\
\mathrm{mg} \mathrm{L}^{-1}\end{array}$ & $\begin{array}{l}\text { FPOC } \\
\mathrm{mg} \mathrm{L}^{-1}\end{array}$ & $\begin{array}{l}\mathrm{CPOC} \\
\mathrm{mg} \mathrm{L}^{-1}\end{array}$ \\
\hline & \multicolumn{10}{|c|}{ Mixed } \\
\hline 1 & 27.7 & 6.37 & 338 & 161.7 & 1.14 & 8302 & 625 & 4.45 & 1.45 & 0.47 \\
\hline 2 & & 6.93 & 525 & 114.0 & 1.60 & 4010 & 663 & 3.98 & 1.79 & \\
\hline 3 & & 7.49 & 1269 & 203.0 & 1.00 & 2633 & 1358 & 2.68 & 1.95 & \\
\hline 4 & 27.3 & 6.68 & 265 & 671.7 & 0.56 & 3551 & 388 & 2.57 & 3.76 & 0.20 \\
\hline 5 & 27.3 & 6.67 & 570 & 421.9 & 0.56 & 8216 & 833 & 5.06 & 2.35 & 0.04 \\
\hline 8 & 26.6 & 6.85 & 600 & 276.3 & 1.14 & 5482 & 789 & 3.59 & 3.15 & \\
\hline 11 & 27.8 & 7.02 & 684 & 630.6 & 0.31 & 4431 & 823 & 1.98 & 1.93 & 0.47 \\
\hline 46 & 29.7 & 6.94 & 270 & 178.9 & 1.51 & 2689 & 455 & 2.44 & 2.71 & 1.11 \\
\hline 47 & 26.0 & 6.97 & 790 & 333.1 & 1.67 & 5356 & 957 & 4.66 & 5.58 & 1.49 \\
\hline 48 & 28.0 & 7.43 & 1280 & 337.9 & 1.11 & 3149 & 1419 & 2.65 & 3.73 & 0.25 \\
\hline 50 & 24.8 & 7.75 & 1290 & 269.2 & 1.84 & 1388 & 1257 & 2.21 & 4.95 & 7.24 \\
\hline \multicolumn{11}{|c|}{ Mountain } \\
\hline 12 & 27.7 & 6.95 & 481 & 851.0 & 1.30 & 3658 & 597 & 1.89 & 8.40 & 0.61 \\
\hline 13 & 23.9 & 7.76 & 762 & 1340.0 & 0.91 & 870 & 790 & 1.28 & 6.87 & 0.42 \\
\hline 14 & 10.2 & 8.62 & 814 & 553.0 & 0.40 & 103 & 808 & 0.94 & 1.81 & 0.03 \\
\hline 15 & 24.6 & 7.71 & 283 & & & 357 & 295 & 1.80 & 1.99 & \\
\hline 16 & 6.7 & 7.01 & 203 & & 0.73 & 1036 & 266 & 0.04 & 0.69 & 0.04 \\
\hline 49 & 26.1 & 7.70 & 1170 & 288.5 & 1.24 & 1623 & 1315 & 1.80 & 3.58 & 0.73 \\
\hline 51 & 25.7 & 7.91 & 1170 & 250.8 & 1.47 & 921 & 1192 & 2.35 & 3.69 & 0.11 \\
\hline 52 & 22.1 & 8.75 & 1960 & 6.6 & 8.84 & 205 & 1833 & 1.57 & 0.59 & 0.00 \\
\hline 53 & 27.0 & 8.06 & 960 & 268.5 & 1.67 & 587 & 1066 & 1.81 & 4.50 & 0.97 \\
\hline 54 & 23.3 & 7.67 & 470 & 59.8 & 1.16 & 704 & 534 & 1.08 & 0.69 & 0.20 \\
\hline 55 & 23.5 & 8.28 & 1230 & 46.7 & 2.44 & 446 & 1340 & 1.40 & 1.14 & 0.09 \\
\hline 56 & 19.7 & 8.21 & 1390 & 55.0 & 2.73 & 562 & 1438 & 2.41 & 1.50 & 0.03 \\
\hline 57 & 17.6 & 7.89 & 2960 & 183.6 & 3.84 & 2572 & 3183 & 3.40 & 7.04 & 0.01 \\
\hline 58 & 15.1 & 7.55 & 2060 & 289.5 & 1.15 & 3872 & 2259 & 1.32 & 3.33 & 6.63 \\
\hline 59 & 18.7 & 7.69 & 3320 & 4.5 & 16.16 & 4103 & 3252 & 2.63 & 0.72 & 0.01 \\
\hline 60 & 11.9 & 8.46 & 1900 & 1.5 & 30.27 & 400 & 1821 & 1.90 & 0.45 & \\
\hline
\end{tabular}


Supplementary Table S3. Isotopic composition (\%o) of each carbon fraction in each sample. Continued on next page.

\begin{tabular}{|c|c|c|c|c|c|c|c|c|c|c|}
\hline \multirow[t]{2}{*}{ Site \# } & \multirow[t]{2}{*}{ Date } & \multirow{2}{*}{$\begin{array}{l}\text { DIC } \\
\delta^{13} \mathrm{C}\end{array}$} & \multicolumn{2}{|c|}{$\mathrm{CO}_{2}$} & \multicolumn{2}{|c|}{ DOC } & \multicolumn{2}{|c|}{ FPOC } & \multicolumn{2}{|c|}{$\mathrm{CPOC}$} \\
\hline & & & $\Delta^{14} \mathrm{C}$ & $\delta^{13} \mathrm{C}$ & $\Delta^{14} \mathrm{C}$ & $\delta^{13} \mathrm{C}$ & $\Delta^{14} \mathrm{C}$ & $\delta^{13} \mathrm{C}$ & $\Delta^{14} \mathrm{C}$ & $\delta^{13} \mathrm{C}$ \\
\hline & & & & & Lowland & & & & & \\
\hline 6 & 7/2/1996 & -19.3 & 100 & -20.6 & & & 136 & -30.8 & 208 & -29.3 \\
\hline 7 & $6 / 27 / 1996$ & -19.4 & 85 & -20.8 & & & & & & \\
\hline 9 & 7/5/1996 & -13.2 & 109 & -16.8 & & & & & & \\
\hline 10 & 7/6/1996 & -21.0 & -145 & -25.3 & 271 & -26.6 & -18 & -31.6 & & \\
\hline 17 & $9 / 20 / 2000$ & -11.8 & 91 & -17.7 & & & & & & \\
\hline 18 & $9 / 13 / 2000$ & -10.4 & 106 & -16.6 & & & & & & \\
\hline 19 & $9 / 13 / 2000$ & -14.5 & 100 & -19.4 & & & & & & \\
\hline 20 & $9 / 16 / 2000$ & -10.5 & 93 & -17.1 & & & & & & \\
\hline 21 & $9 / 16 / 2000$ & -11.9 & 104 & -18.7 & & & & & & \\
\hline 22 & $8 / 26 / 2002$ & -13.1 & 59 & -16.8 & & & & & & \\
\hline 22 & $12 / 2 / 2002$ & -12.9 & 102 & -14.3 & & & & & & \\
\hline 22 & $1 / 15 / 2003$ & -9.5 & 98 & -13.9 & & & & & & \\
\hline 23 & $8 / 28 / 2002$ & -10.9 & 111 & -16.4 & & & & & & \\
\hline 23 & $12 / 5 / 2002$ & -9.5 & 104 & -13.2 & & & & & & \\
\hline 24 & 7/3/1996 & -10.0 & 118 & -15.6 & 245 & -27.0 & 125 & -25.6 & 12 & -27.6 \\
\hline 24 & $9 / 17 / 2000$ & -10.5 & 106 & -17.3 & & & & & & \\
\hline 24 & $1 / 26 / 2003$ & -16.3 & 86 & -20.3 & & & & & & \\
\hline 25 & $9 / 12 / 2000$ & -11.5 & 111 & -17.8 & & & & & & \\
\hline 25 & $1 / 24 / 2003$ & -11.2 & 98 & -16.5 & & & & & & \\
\hline 26 & $9 / 11 / 2000$ & -11.6 & 102 & -18.4 & & & & & & \\
\hline 27 & $9 / 11 / 2000$ & -12.0 & 96 & -18.3 & & & & & & \\
\hline 28 & 7/3/1996 & -14.9 & 128 & -17.7 & & & 139 & -28.6 & 143 & -28.1 \\
\hline 28 & $9 / 11 / 2000$ & -16.0 & 100 & -19.5 & & & & & & \\
\hline 28 & $1 / 18 / 2003$ & -20.4 & 88 & -22.6 & & & & & & \\
\hline 29 & 7/4/1996 & -20.5 & 62 & -19.8 & & & & & & \\
\hline 29 & $9 / 10 / 2000$ & -21.8 & 74 & -21.8 & & & & & & \\
\hline 30 & $9 / 11 / 2000$ & -12.9 & 94 & -19.2 & & & & & & \\
\hline 31 & $9 / 10 / 2000$ & -19.0 & 28 & -20.0 & & & & & & \\
\hline 32 & $1 / 31 / 1995$ & & & & 181 & -29.1 & & & & \\
\hline 32 & 6/20/1995 & & & & 336 & -29.1 & 121 & -29.1 & & \\
\hline 32 & 7/6/1996 & -25.4 & 141 & -24.4 & 130 & -29.3 & 138 & -29.8 & & \\
\hline 32 & $7 / 15 / 2002$ & -27.2 & 118 & -26.2 & & & & & & \\
\hline 32 & $11 / 12 / 2002$ & -24.2 & 99 & -24.1 & & & & & & \\
\hline 33 & $7 / 13 / 1995$ & & & & 151 & -29.3 & & & & \\
\hline 33 & 7/13/2002 & -25.0 & 115 & -23.9 & & & & & & \\
\hline 34 & $12 / 12 / 1995$ & & & & 107 & -29.1 & & & & \\
\hline 34 & $7 / 13 / 2002$ & -27.5 & 84 & -26.3 & & & & & & \\
\hline 34 & $11 / 3 / 2002$ & -26.5 & 102 & -25.4 & & & & & & \\
\hline 35 & $7 / 15 / 2002$ & -26.3 & 90 & -25.2 & & & & & & \\
\hline 36 & $7 / 19 / 2002$ & -25.9 & 89 & -24.7 & & & & & & \\
\hline 36 & $11 / 6 / 2002$ & -26.8 & 95 & -25.7 & & & & & & \\
\hline 37 & $3 / 30 / 1995$ & & & & 169 & -29.1 & & & & \\
\hline 38 & $3 / 29 / 1995$ & & & & 175 & -29.2 & & & & \\
\hline 38 & 4/2/1995 & & & & 171 & -29.4 & & & & \\
\hline 39 & $4 / 2 / 1995$ & & & & 167 & -29.4 & & & & \\
\hline 40 & $7 / 5 / 1996$ & -21.0 & 124 & -22.4 & 96 & -29.9 & 113 & -31.5 & & \\
\hline
\end{tabular}


Supplementary Table S3 continued. Isotopic composition (\%o) of each carbon fraction in each sample.

\begin{tabular}{|c|c|c|c|c|c|c|c|c|c|c|}
\hline \multirow[t]{2}{*}{ Site \# } & \multirow[t]{2}{*}{ Date } & \multirow{2}{*}{$\begin{array}{l}\text { DIC } \\
\delta^{13} \mathrm{C}\end{array}$} & \multicolumn{2}{|c|}{$\mathrm{CO}_{2}$} & \multicolumn{2}{|c|}{ DOC } & \multicolumn{2}{|c|}{ FPOC } & \multicolumn{2}{|c|}{ CPOC } \\
\hline & & & $\Delta^{14} \mathrm{C}$ & $\delta^{13} \mathrm{C}$ & $\Delta^{14} \mathrm{C}$ & $\delta^{13} \mathrm{C}$ & $\Delta^{14} \mathrm{C}$ & $\delta^{13} \mathrm{C}$ & $\Delta^{14} \mathrm{C}$ & $\delta^{13} \mathrm{C}$ \\
\hline \multicolumn{11}{|c|}{ Lowland } \\
\hline 41 & $6 / 23 / 1996$ & -13.8 & 72 & -21.1 & 175 & -29.3 & 29 & -30.8 & & \\
\hline 42 & $6 / 22 / 1996$ & -14.6 & 2 & -22.1 & & & & & & \\
\hline 43 & 7/1/1996 & -17.9 & 113 & -22.5 & 116 & -29.9 & 59 & -30.0 & & \\
\hline 44 & $7 / 2 / 1996$ & -17.6 & 110 & -17.1 & & & & & & \\
\hline 45 & $6 / 25 / 1996$ & -15.4 & 68 & -19.5 & 172 & -29.7 & 55 & -29.8 & 85 & -28.7 \\
\hline \multicolumn{11}{|c|}{ Mixed } \\
\hline 1 & $1 / 10 / 1995$ & & & & 201 & -29.4 & -85 & -28.3 & -183 & -28.7 \\
\hline 1 & $6 / 16 / 1995$ & & & & 138 & -29.6 & -157 & -28.7 & -127 & -27.8 \\
\hline 1 & 7/6/1996 & -17.7 & 76 & -21.4 & & & & & & \\
\hline 1 & $7 / 12 / 2002$ & -18.3 & 30 & -20.5 & & & & & & \\
\hline 1 & $7 / 12 / 2002$ & -18.7 & 42 & -20.4 & & & & & & \\
\hline 2 & $8 / 26 / 1991$ & -12.7 & 36 & -18.6 & & & & & & \\
\hline 3 & $8 / 12 / 1991$ & -11.4 & -29 & -18.5 & & & & & & \\
\hline 4 & $1 / 19 / 1995$ & & & & 331 & -28.7 & -73 & -27.4 & -148 & -27.4 \\
\hline 4 & 7/8/1996 & -15.8 & 96 & -20.7 & 155 & -28.8 & -49 & -29.8 & & \\
\hline 5 & $5 / 3 / 1995$ & & & & & & -329 & -27.3 & -93 & -26.1 \\
\hline 8 & $6 / 27 / 1996$ & -13.8 & 49 & -19.4 & 197 & -28.0 & -131 & -28.3 & -233 & -26.5 \\
\hline 11 & $5 / 6 / 1995$ & & & & 199 & -28.6 & -440 & -26.8 & -146 & -27.6 \\
\hline 46 & $11 / 7 / 1996$ & -13.7 & 22 & -19.4 & 231 & -29.6 & -24 & -28.9 & -18 & -28.4 \\
\hline 47 & $11 / 8 / 1996$ & -11.6 & -196 & -17.7 & 157 & -29.2 & -6 & -28.5 & -43 & -28.1 \\
\hline 48 & $11 / 8 / 1996$ & -11.5 & -138 & -18.4 & 158 & -29.5 & -59 & -28.6 & -124 & -28.2 \\
\hline 50 & $11 / 5 / 1996$ & -11.1 & -142 & -18.7 & & & & & & \\
\hline \multicolumn{11}{|c|}{ Mountain } \\
\hline 12 & $11 / 14 / 1994$ & -9.9 & -154 & -15.8 & & & & & & \\
\hline 13 & $11 / 15 / 1994$ & -6.9 & -116 & -14.2 & & & & & & \\
\hline 13 & $5 / 11 / 1995$ & & & & & & & & -30 & -27.5 \\
\hline 14 & $11 / 20 / 1994$ & -5.4 & -61 & -14.9 & & & & & & \\
\hline 15 & $11 / 16 / 1994$ & -6.9 & 15 & -14.5 & & & & & & \\
\hline 16 & $5 / 15 / 1995$ & & & & & & -221 & -25.6 & 51 & -27.6 \\
\hline 49 & $11 / 5 / 1996$ & & & & 271 & -28.7 & -80 & -28.1 & 35 & -28.6 \\
\hline 51 & $11 / 1 / 1996$ & -6.1 & -155 & -13.7 & 153 & -27.9 & -73 & -27.6 & 80 & -28.3 \\
\hline 52 & $10 / 21 / 1996$ & -2.6 & -148 & -10.8 & 27 & -21.8 & 19 & -23.7 & -19 & -23.8 \\
\hline 53 & 11/1/1996 & -10.0 & -151 & -17.5 & 111 & -29.0 & -301 & -27.1 & 75 & -28.5 \\
\hline 54 & $10 / 27 / 1996$ & -3.5 & -45 & -11.1 & & & & & & \\
\hline 55 & $10 / 27 / 1996$ & -3.3 & -248 & -11.3 & & & & & & \\
\hline 56 & $10 / 27 / 1996$ & -3.3 & -273 & -11.7 & 221 & -25.2 & -89 & -24.3 & 17 & -26.2 \\
\hline 57 & $10 / 26 / 1996$ & -3.0 & -645 & -11.5 & & & & & & \\
\hline 58 & $10 / 23 / 1996$ & -2.4 & -749 & -10.7 & & & -613 & -24.6 & -208 & -25.9 \\
\hline 59 & $10 / 23 / 1996$ & -2.8 & -523 & -10.9 & -222 & -23.3 & -257 & -24.6 & -353 & -26.4 \\
\hline 60 & $10 / 24 / 1996$ & -2.0 & -109 & -11.3 & & & & & & \\
\hline
\end{tabular}




\section{Supplementary Figure}

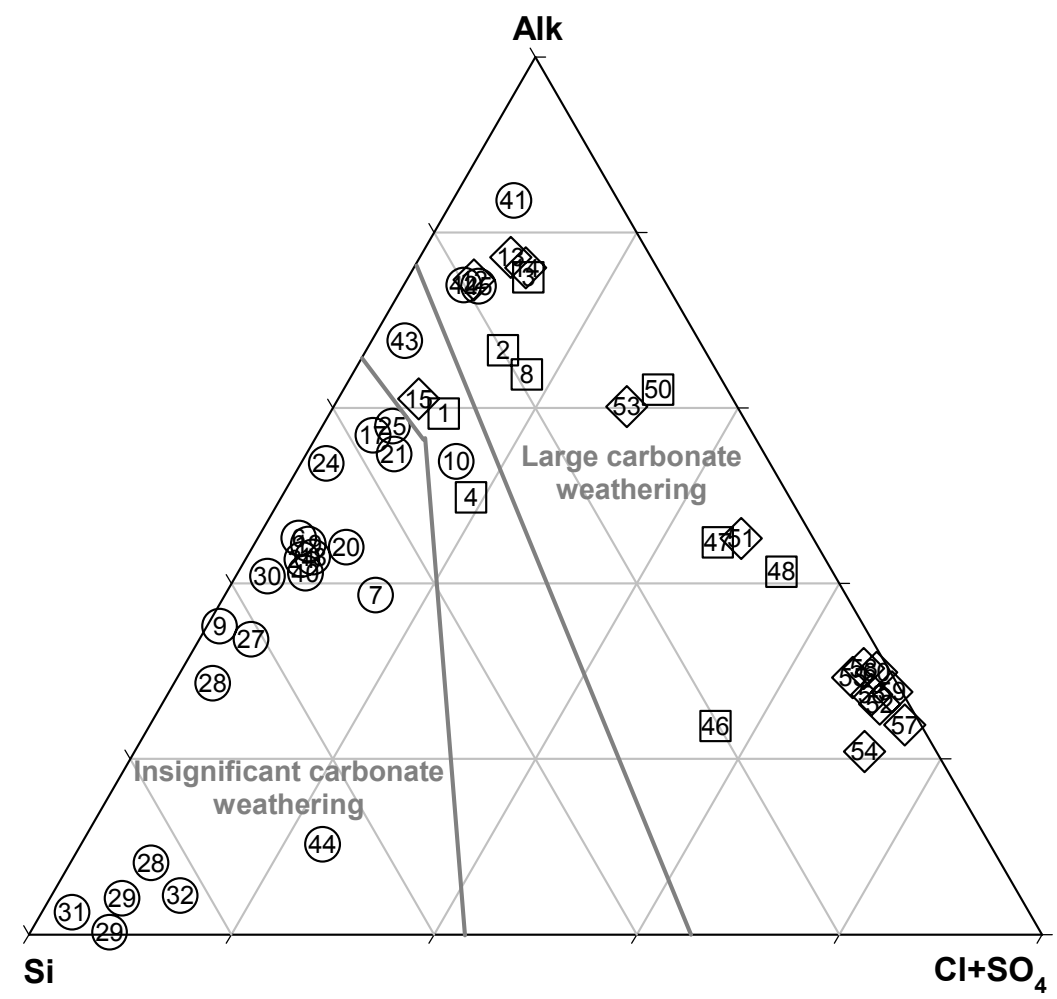

Supplementary Figure S1. Relative proportions of silica $\left(\mu \mathrm{mol} \mathrm{L}{ }^{-1}\right)$, alkalinity $\left(\mu e q \mathrm{~L}^{-1}\right)$, and $\mathrm{Cl}^{-}+\mathrm{SO}_{4}{ }^{2-}\left(\mu \mathrm{eq} \mathrm{L}^{-1}\right)$, indicative of dominant weathering regimes controlling the dissolved load ${ }^{15}$. Legend is as in Fig. 1. Only samples with ${ }^{14} \mathrm{C}$ DIC analyses are shown. Data were not corrected for seasalt aerosols. Rivers falling near the alkalinity and $\mathrm{Cl}^{-}+\mathrm{SO}_{4}{ }^{2-}$ vertices are cation-rich and drain areas rich in carbonate sediments and evaporites + carbonates, respectively, whereas rivers draining cation-poor aluminosilicates cluster near the silica vertex $^{15}$. We delineated regions of high vs. insignificant carbonate weathering contributions $^{15}$. A heterogeneous set of five intermediate sites was assigned to the carbonate influence group. Seven additional lowland sites where silica, 
alkalinity, and major anions were not measured were assumed to be carbonatefree based on dominant lithology, observations from neighbouring rivers, or previous studies. All mountain and mixed sites, and five lowland sites (sites 10, $41,42,43$ \& 45), are identified as carbonate-influenced. 